\title{
Review Essay: Are the Tulama and Wallo Oromo Habasha?
}

\author{
Asafa Jalata \\ Department of Sociology, The University of Tennessee, Knoxville, TN, USA \\ Email:ajalata@utk.edu
}

How to cite this paper: Jalata, A. (2021) Review Essay: Are the Tulama and Wallo Oromo Habasha? Sociology Mind, 11, 125146

https://doi.org/10.4236/sm.2021.114010

Received: August 22, 2021

Accepted: October 9, 2021

Published: October 12, 2021

Copyright (c) 2021 by author(s) and Scientific Research Publishing Inc. This work is licensed under the Creative Commons Attribution International License (CC BY 4.0).

http://creativecommons.org/licenses/by/4.0/

\begin{abstract}
In his book, Brian J. Yates (2020) overgeneralizes the experiences of a few Oromo collaborator individuals from the Tulama and Wallo Oromo to the affairs of these Oromo groups. It claims that the Tulama and Wallo Oromo participated in the construction of the modern Ethiopian state between 1855 and 1913 and, in the process, became Habasha by abandoning their Oromo culture and identity. If the colonization of peoples would transform the cultures and uniqueness of the conquered peoples, today, the entire world population would have become the English and the French by rejecting their respective cultures and identities. But colonialism only creates collaborative classes from the dominated population groups to use them as intermediaries to facilitate the exploitation and oppression of the subaltern groups. The Tulama and Wallo Oromo case is not different. The Oromo intermediaries from these Oromo groups were assimilated to the Amhara/Habasha culture and state to promote their interests and the interest of their colonial masters at the cost of the Oromo masses. By using the critical and political economy analytical approaches, this review essay debunks the claims that the author of the book makes by ignoring the history, culture, and identity of the Oromo people, which have been suffering under Habasha colonialism in general, and Amhara colonialism in particular, for more than a century.
\end{abstract}

\section{Keywords}

Tulama and Wallo Oromo, Oromia, Gobana and Menelik, Habasha, Competing Nationalisms, Oromo, Amhara-Tigray, The Manz/Shawa Kingdom, The Ethiopian Colonial State

\section{Introduction}

The author alleges that the Northern Oromo, namely the Tulama and Wallo Oromo, became Habasha through cultural and political interactions with the 
Amhara kingdom of Manz, northern Shawa, by abandoning their cultural norms and Oromo identity and formed the modern Ethiopian state between 1855 and 1913. His specific objective is to liberate the Tulama and Wallo Oromo history from Oromo nationalism, which mobilizes the larger Oromo society. By including them in the Habasha peoplehood or community, Yates claims to reject ethno-racial categories that essentialize Oromo and Amhara histories and undermine the reality of "the multiethnic Habasha cultural community in creating modern Ethiopia." The author criticizes Ethiopian studies for using ethno-racial categories and Oromo studies to silence "the Northern Oromo groups who played a role in creating modern Ethiopia." By rejecting the concept of ethnonational or ethnic categories such as Oromo, Amhara, and Tigrayan, Yates defines the $\mathrm{Ha}$ basha as a cultural community. However, Yates does not explain how the relationship between the indigenous Oromo and the expanding Amhara gradually emerged and evolved into conflict, series of wars, colonization, and contradictions. He considers the Tulama and Wallo Oromo as raw material from which the Habasha constructed their peoplehood, nation, and state. If, as he claims, both the Northern Oromo and the Amhara and Tigray ethnonational groups, which he calls the Habasha, jointly constructed the Ethiopian state, why has this state continued to entirely reflect the Amhara culture, identity, language, and religion? Or did the Oromo culture, identity, religion, and language lack the substance needed to construct a state?

Yates focuses on the biographical narratives of Oromo collaborators such as Michael of Wallo and Gobana of Tulama. They sided with the Amhara and Tigrayan kings to benefit their personal interests at the cost of the larger Oromo society. Nevertheless, the author does not explain why some members of the Oromo elite chose to join the Amhara ruling class. He should have also explained why these individuals abandoned their Oromo culture, language, Islam, or the indigenous Oromo religion known as Waqeeffannaa and accepted the political, cultural, and economic practices of the Amhara. By focusing on personal and family relationships between the dominant Amhara elite and the subordinate and collaborator Oromo elite, he does not explain how the Oromo farmers and pastoralists of Tulama and Wallo were negatively affected by these relationships. In reality, the relationship between the Amhara kingdom and the affected Oromo groups involved various forms of conflict, conquest, war, banditry, robbery, slavery, and expropriation of cattle and land. This relationship also involved resistance from the Oromo masses and certain elites. However, Yates conveniently ignores to deal with these issues. How did the relationship between the Tulama and Wallo Oromo and the Amhara/Habasha evolve? How did the independent Oromo communities of Tulama and the Wallo become dependent on Habasha?

\section{The Evolution of the Amhara Kingdom of Manz}

How did this kingdom evolve? This Amhara kingdom evolved from the ancient 
kingdom of Axum, which emerged through the cross-fertilization of Arabian and African cultures brought together by migration, commerce, and religion (Michels, 1991: pp. 63-80; Jones and Monroe, 1961: pp. 6-7; Pankhurst, 1961: p. 389; Greenfield, 1965: pp. 16-22; Hable Selassie, 1972) in the first century A.D. (Markakis, 1974: p. 13; Gamst, 1970: p. 375). The assimilation of cultures probably started to take place in the first half of the first millennium B.C. (Michels, 1991: pp. 63-80). The kingdom had adopted Orthodox Christianity in the fourth century A. D. through the commercial contact it had with the Greco-Romans. However, the rise of Islam in the seventh century A. D. in Arabia and its extension to the Horn of Africa through commerce gradually isolated the Axumite kingdom and brought about the decline of its business and civilization (Jones and Monroe, 1961: pp. 6-7). Gradually the domain became "a Christian island in a Muslim sea" (Pankhurst, 1961: pp. 55-56), as Muslims occupied the Red Sea coasts such as Massawa, Suakin, Dahlak, Begas, and other ports to loot wealth and seize "strong, able-bodied and beautiful women" (Pankhurst, 1961: pp. 55-56). The final death blow for the kingdom of Axum came from the Agao dynasty, which ruled the descendants of the Axumites from then until 1270 when the Amhara dynasty emerged and overthrew it (Markakis, 1974: pp. 13-14). By assimilating with the local populations, mainly the Agao and Qimant, they gradually emerged as the Amhara, most likely taking their name from the region they initially settled. Political fragmentation existed until the Zagwe/Agao dynasty emerged at Lalibela, a town in Lasta (district north of Wallo), in the middle of the eleventh century.

Between 1137 and 1270, the Agao or Zagwe (Z-Agao) dynasty ruled the postAxumite Empire; in 1270, the first Amhara king, Yekuno Amlak, defeated and killed the last Zagwe king and replaced him. With assimilating with the local populations, mainly the Agao, they later emerged as the Amhara. Amhara-Tigray peoplehood emerged by blending the Axumite remnants and other peoples. Through this process, the two Abyssinian peoples (the Amhara and Tigray), who later preferred to call themselves Habasha or Abyssinians, emerged with a common religion, tradition, and customs. It was necessary to accept Orthodox Christianity, learn at least one Habasha language (Amharnga or Tigranga), and get their businesses to be Habasha or Amhara or Tigray (Stitz, 1970: p. 30). The Abyssinians or Habasha, particularly the Amhara, continued to assimilate the conquered peoples, and Amharaization meant destroying the identity of the colonized populations groups. "To avoid dilution and submersion of [Amhara] fundamental characteristic..." John Markakis (1974: p. 32) writes, "it was essential to retain political supremacy and to promote assimilation along lines dictated by selfpreservation."

The establishment of military colonies, the evangelization of the indigenous populations, and assimilation were the continuous processes of expansion and Amharaization, which they later called Ethiopianization (Tamrat, 1972). Explaining the relation among the monarchy, the church, and the people, Markakis 
(1974: p. 33) notes that "Interdependent and mutually reinforcing, throne and church have been the twin foci of the forces of societal unity." The monarchical and church institutions played leading roles in maintaining Amhara dominance. In the thirteenth century, the Amhara ruling class produced a document known as the Kebra Nagast (Glory of the kings) that rationalized and legitimized the monarchy by linking its genealogical descent to the ancient king of Israel, Solomon (Budge (tr.), 1932). By tracing "the origin of the Ethiopian state in the era of Solomon, the legend endowed the Ethiopian nation with a notable ancient past. Tradition reckons history from that time, hence the claim to three thousand years of existence" (Markakis, 1974: p. 29).

Based on this mythical claim, the Amhara monarchy began to consider itself a Solomonic dynasty. The so-called Solomonic monarchy remained in Abyssinian or Ethiopian culture from 1270 to 1974, when the military regime overthrew the Haile Selassie government. The first Amhara king, Yekuno-Amlak, claimed the restoration of the Solomonic dynasty in 1270 when he emerged as the first Amhara negus (king) and shifted the geopolitical center from Lalibela, Lasta, to Manz, northern Shawa plateau (Pankhurst, 1961: p. 64). The successive Amhara ruling classes continued to use the mythical claim of the Solomonic dynasty and Orthodox Christian ideology to perpetuate their dominant political economies. "The Solomonic myth, introduced with the decline of the Axumite Empire... to patch up the cracking wall of unity" (Abir, 1968: pp. xviii-xviii-xix) was combined with Orthodox Christianity to organize the Amhara-Tigrayan peoples. Claiming their descent from King Solomon and their election by God, the monarchs placed themselves at the top of the secular and ecclesiastic hierarchies; they had the absolute right to appoint and dismiss church and government officers (Hoben, 1970: p. 218). The monarchies maintained political order through the loosely organized army, Orthodox Christian ideology, and the monopolization of firearms imports starting from the fifteenth century; they had control over the appointment and dismissal of officials and the ability to mobilize human and economic resources in the kingdom and beyond through their officials. The Amhara assimilated the conquered peoples, and Amharization meant destroying the identity of the colonized populations (Hoben, 1970: p. 32).

When the Axumites expanded their territory from Axum southward, they occupied land, and later their descendants claimed usufructuary rights to it (Pankhurst, 1968: pp. 563-572). The land occupied by the original colonists was called the rist land. Rist rights were initially claimed based on occupancy, conquest, and clearance of forest land (Markakis, 1974: p. 75). The monarch collected tributes on all lands under his domain (except church land) and revoked rist-holder rights in failure to pay homage. He took vacant land; possessed unclaimed and unused land; confiscated land as punishment for crimes and political opposition; took the land of hereditary families dying out; and expanded his territory through colonization and land expropriation (Markakis, 1974: p. 82). The kingdom furthered its territorial expansion through military colonies where 
large-scale Christian settlements occurred (Tamrat, 1972: p. 100). The king gave the land of the conquered population as gult ("fief") for military, administrative, and religious service; the colonizers imposed heavy dues on the colonized people (Tamrat, 1972: pp. 98-99). The conquerors intensified the assimilation process by expropriating the means of production of the occupied population, attacking their identity, and imposing Christianity and Abyssinian languages and customs. They enslaved those who resisted colonial domination. Tadesse Tamrat (1972: pp. 98-99) notes that "The juridical effect of a fresh military conquest was to reduce all the conquered people and their entire belongings to the king's absolute power. He appropriated all the people their lands and reserved every right to dispose of them according to his wishes."

The gult land charter was begun during the Axumite kingdom when a certain king gave land for the Cathedral of Aksum. The state granted the gult fief-style rights as a reward for services and as endowments. The monarch-appointed regional rulers, waived part of taxing power over the cultivators and provided the rulers with the gult land (Stahl, 1974: p. 19). The gult holders received tributes in cloth, grain, honey, salt, camel, sheep, and cattle; they extracted between onetenth and one-third of the farmer's product (Stahl, 1974: p. 19). The state gave the ruling class, including the church officials gult rights, the right to collect tributes and labor, and other services from the farmers who lived on the land and had some authority over them. Gult rights could be temporary, lifetime, or hereditary (rist-gult) depending on the giver's interest and power and the receiver's services. The crown and its officials allocated lands to members of the royal family, aristocracy, court, provincial governors, clergy, and local functionaries in return for loyal service.

But the king could cancel the rights at any time if the gult-holder was found disloyal. Land rights indicated class: Whereas the ordinary farmer had a rist right, the ruling class simultaneously had rist and gult or rist-gult rights. Artisans, former slaves, and strangers had no right to land; hence they were tenants. The various mechanisms of surplus extraction from the producers included asrat (tithe) on land, tribute on agricultural production (between a fifth and a third), and tax on livestock. The cultivators were also required to provide compulsory military service and corvee labor, give gifts honoring their lords' appointments, and contribute to various ceremonial feasts (Crummey, 1980: p. 127). The farmers supported government officials and soldiers by billeting and supplied provisions (dirago) whenever necessary (Caulk, 1978: pp. 457-493; Pankhurst, 1967: p. 37). The ruling class depended mainly on tribute collection from cultivators and handicraft workers. Taxes from traders increased government revenue. As we see below, Habasha's colonial expansion initially expanded modified tributary productive relations into Oromo regions. Yates fails to explain the contradictory relationship between the colonizers and the colonized peoples in Abyssinia proper and extends his analysis to the population groups such as the Oromo, which they occupied and incorporated into the Ethiopian Empire during the last 
decades of the nineteenth century.

\subsection{The Homeland of the Northern Oromo and the Amhara}

Following the intellectual footsteps of Amhara and Ethiopianist scholars, Yates argues that the Oromo moved to the north in the sixteenth century. He also asserts that after contacting the Habasha state and people, the Oromo gadaa system (the Oromo governance system) disintegrated. Then the Oromo warrior class emerged and assimilated into Amhara/Habasha cultural and political norms and became Oromo Habasha. In doing this, he glosses over the recent historical discoveries on the movement of the Oromo from north to south, from their original homeland, near the Bule Nile, by certain historians, anthropologists, linguists, and sociologists such as Mekuria Bulcha (2011), Mohammed Hassen (2015), Daniel Ayana (2019) and Muhammad Shamsaddin Megalommatis (2007). It is necessary to examine the evolution of the colonial relationship between certain Oromo groups and the Amhara kingdom in particular and the Oromo nation and the Abyssinian/Ethiopian Empire in general. "[The emergence of] the Zagwe dynasty... might have been an assertion of the indigenous population to recover their usurped sovereignty... The dynasty came to an end by intrigues staged by remnants of the oldest Axumite Kingdom who had fled to the south, to what is today the region to the extreme northern part of Shawa, to solicit the hospitality and assistance of the Oromo people of the region" (The Oromos: Voice against Tyranny, 1971). Gradually, in search of land, slaves, cattle, and other resources, the Amhara kings and people expanded their colonial expansion to the Oromo communities of northern Shawa. Mekuria Bulcha explains that "the Gaalaan and the Amhara were fighting in the twelfth, thirteenth and fourteenth centuries. The Gaalaan, who the Tuulama Oromo considers as angafa (the senior gosa or the firstborn), is numerically the largest Oromo gosa [clan] cluster" (Bulcha, 2011: pp. 221-222).

$\mathrm{He}$ considers the northern Shawa plateau the ancient country of the Oromo nation by refuting the claims that the Oromo came to the present Oromia/Ethiopia from another place (Bulcha, 2011: pp. 131-222). Bulcha (2011) characterizes the Shawa plateau as the "cradle of Oromo civilization and springboard for Amhara expansion" to the Oromo country. According to the Oromo oral tradition (Bulcha, 2011: p. 131; Oromia Culture and Tourism Bureau (OCTB, 2006: p. 74)), the original center of $A b b a a$ Gadaa, the president of the Oromo assembly known as caffee, and the center of Abbaa Muuda, the leader of Oromo indigenous religion known as Waaqeefannaa, was Abbaya or Mormor (ancient name for the Blue Nile). Then it moved to Odaa Nabee (near Finfinnee) in the fifth century A. D. (Oromia Culture and Tourism Breau (OCTB, 2006: p. 74). The Amhara came to the northern Shawa plateau almost five centuries after the Gaalaan Oromo. Between the ninth and fourteenth centuries, isolated Christian communities trickled to the south and gradually formed the Christian kingdom of Manz/Shawa (The Oromos: Voice against Tyranny, 1971: p. 11). Initially, Chris- 
tian Amhara priests moved to the neighboring Oromo communities:

In the $13^{\text {th }}$ century, the Abyssinian Christian Kingdom started sending organized missionaries to the Oromo regions. Under their Abba Boku and other politico-religious leaders, the Oromo people tried hard to save their homelands from invasion by resisting Christianity which the imperialists used as a vanguard force of aggression. The Oromos, true to their love of freedom and dignity, burnt the Christian villages that were newly established among them. To overcome this problem, the Christian priests began to compromise their religious practices with the Oromos. [They started to celebrate] the Maskal and the Timket... Besides this, the Christian kingdom sent troops to settle in areas where Christian churches started evicting the Oromos, thereby building monasteries to defend priests (The Oromos, 1971: pp. 11-12).

Mohammed Hassen (2015: p. 63) also notes that some Oromo clans lived in the Shawan plateau before the Amhara arrived there. Yikunno Amlak (1270-85) established the Shawan kingdom and the Orthodox church in the Oromo community of the northern Shawan plateau (Hassen, 2015: pp. 78-79). How did the geopolitics of Shawa and the Oromo collaborators help Menelik, the leader of the Shawa kingdom expand his territories? As noted above, starting in the thirteenth century, the Christian Amhara began to penetrate their neighboring northern Oromo communities through missionaries and colonial agents. The Amhara group called Menz "remained as a pocket of resistance in a rugged mountains area... located in the northern horn of Shawa. As early as the $17^{\text {th }}$ century, the Menz under the leadership" of Kristos Warada Qal (1696-1703) and Sahile Selassie (1813-1847) began to attack certain Oromo clans (The Oromos: Voice against Tyranny, 1971: pp. 11-12). Starting with the Metta Oromo, Sahile Sellasie, one time, raided and butchered four thousand five hundred Oromo and enslaved the remaining men, women, girls, looted grains and herds, and burned Oromo communities (The Oromos, 1971: p. 14). As a religion and state ideology, Christianity created a bridge between Europeans and Amhara rulers. Around 1840, the British and French governments supplied Sahle Selassie, Menelik's grandfather, with firearms "so that he could spread the seeds of civilization [i.e., Christianity] among the Gallas [Oromos]" (The Oromos, 1971: p. 14).

European missionaries, explorers, and merchants convinced their governments to support the Habashas against the Oromo and others they considered "pagan" and "savage." Sahle Selassie's forces raided 84 times in one year against the Tulama Oromo; in one attack, his forces massacred about 4500 persons, looted some 43,000 animals, and enslaved more than 1000 Oromo (The Oromos, 1971: p. 14). But, whenever the Amhara established their settlements among the Tulama Oromo, the Oromo collectively chased the settlers away or killed them (The Oromos, 1971: p. 14). The result was that the Abyssinians could not effectively occupy any Oromo land during this period. Sahile Selassie raided and butchered Oromo clans and looted their resources and enslaved some of them. 
(The Oromos, 1971: p. 14). According to The Oromos (1971: p. 14), Menelik, the grandson of Sahile Selassie, using the geopolitics of the northern Shawa, the Menz Amhara army, and the assistance of European colonial powers, completed the colonization of the larger Shawa and later the whole Oromia and the other colonized territories.

The system of extermination and enslavement reached its climax under Menelik, who proved himself to be the greatest of all the butchers. Menelik completed his ancestors' process of conquest of Shawa. Furthermore, Menelik subjugated the south, southeast, southwest, Oromos, Wallaytas, Kaffas, and other groups. Menelik used the booties and slaves from these conquered territories as a springboard for achieving his broad colonial and imperial scheme to dominate Ethiopia [mainly] for the benefit of his Menz group. The conquest, therefore, has a special significance for all groups presently suffering under the yoke of Menz subjugation. [The foreign powers provided advice and material supplies] to Menelik's subjugation of the southern territories... The conquered territories also helped Menelik to raise a large army that can live off the subjugated groups. [Menelik compelled] every family in the annexed territories to feed several soldiers and their beasts of burden. A colonized man who survived the wanton and... onslaught of Menelik's army was either taken and sold as a slave or subjected to humiliation by the stationing of soldiers who had the license to rape his wife and daughters. Even an officer of the lowest rank in Menelik's army was entitled to the personal service of the colonized people [and] forced [them] to build and fence his house and provide all forms of domestic services (The Oromos, 1971: pp. 15-16).

Using the Orthodox Christian ideology, Menelik gained access to European technology, weapons, administrative and military expertise, and other skills that allowed him to consolidate the modern Ethiopian clientele state. Furthermore, he mobilized the Oromo collaborators class elements such as Gobana Dacei, Habte Giorgis, and Balcha Abbaa Nafso and conscripted Oromo soldiers to colonize Oromia and other territories. Menelik and Haile Selassie established settler colonialism by establishing and consolidating the Habasha political and religious institutions, Garrison, and other cities, creating and reducing an intermediary class, colonial education, the colonial landholding system, and the media. However, the colonization a few Oromo groups started before Menelik, during the reign of Amda Tsion, between 1487 and 1494, the Christians intensified their expansion into the Oromo communities in two ways; first, they annexed "the areas occupied by the Christian communities dispersed among the Oromo in southern Shawa" (The Oromos, 1971: p. 12). Second, they forcefully converted some Oromo to Christianity by killing confident Oromo political and religious leaders. As one source noted, "If a Christian [would] kill... [an Oromo]... it would be considered for him ... an offering to God" (Quoted in the Oromos, 1971: p. 12). The Oromo communities fought against the invading Christian kingdom until 
the advent of Ahmed Gragn, a Muslim imam who conquered the Shawa kingdom and other independent communities between 1527 and 1543 (Faqih, 2003). Certain Oromo groups suffered immensely from the jihad war because they were involved in both sides of the Christians and the Muslims (Hassen, 2015: p. 88). When the Christian and the Muslim forces were contesting in the Horn of Africa for power and control of resources such as lands, northern and southern Oromo fought to liberate their territories and the conquered Oromo communities from the two invaders. When the Abyssinian Christian kingdom attacked the Tulama Oromo clans such as Gaalaan, Yaya, Waji, Abichu, and others, the Muslim empire builders also attacked the Oromo branches living in the area is currently called Somalia and other areas (OCTB, 2006: p. 74). Before and after the sixteenth century, the Christian empire builders from the north and the Muslim empire builders from the south attacked the Oromo.

Consequently, their gadaa assemblies moved from one center to another. The Oromo moved their main gadaa center from Odaa Mormor (near the Blue Nile) to Odaa Nabee (in Shagar). Later they moved it to Odaa Roba and later to Madda Walaabuu in Bale; in these centers, two different institutions, gadaa, and qaaluu, "served as the center of both politics and religion for the Oromo clans living in the area" (OCTB, 2006: p. 56). The gada system initially renewed and centralized at Odaa Roba, "which [was] a politico-religious center for several hundred years before the fourteenth century;" "Odaa Roba had become a new holy politico-religious center of the Oromo people at large that the various representatives of Oromo groups had periodically visited from all directions for such celebrations like Jilaa Gada and [pilgrim]" (OCTB, 2006: pp. 90-91). Later, the politico-religious center of Odaa Roba moved to Madda Walaabuu (the spring of freedom) probably because of the pressure from the Muslim empire-builders of Somalia. Consequently, the Bale Oromo living around Madda Walaabu, with the support of other Oromo branches, reorganized and reconsolidated their political power and the gadaa system starting from the eleventh century (OCTB, 2006: p. 104). Between 1518 and 1519, the general assembly of the Oromo nation was held for six months at Madda Walaabuu to deliberate how to liberate the Oromo country from the Christian and Muslim invaders; delegates from different parts of the Oromo country participated in this assembly (OCTB, 2006: p. 104).

The main question Walaabuu Jiloo, Abbaa Gadaa of Madda Walaabuu, asked at the general community was "Maal Taana?" ("What are we going to be?") After discussions and deliberations, the group identified the main enemies of the Oromo people as the Christian and Muslim empire builders attacking the Oromo country and people to kill, take their lands and other resources, and force them to abandon their culture, religion, and identity. The assembly also passed major resolutions to mobilize the entire nation to liberate their country and conquered brothers and sisters. The history of Madda Walaabuu demonstrates that the most significant revival and reorganization of the gadaa institution occurred at the beginning of the sixteenth century (OCTB, 2006: p. 104). Since this 
century, the renewal and reorganization of the gadaa system involved fundamental changes; these changes included rules, regulations, and objectives. There were two main objectives: "Firstly, it... aimed [at] defending the gadaa system and the Oromo people from the pressure of Islam. Secondly, [to build\} the military power of the people and enable them to regain their old area of settlement lost as the result of the [ongoing] wars of the Christian and Muslim states ... The changes in ... the formulation of new rules and regulations were, therefore, actions of paramount importance to realize those objectives" (OCTB, 2006: p. 104). As a result, the Oromo decided "[to launch] at least one Butta military campaign... every eight years in all directions to regain[ the lost] old settlement areas of the Oromo people [...] and unite them with their relatives that remained behind. [It] was [also] decided to strengthen Muuda religious pilgrimage made to the seat of the Qaallu every eight years" (OCTB, 2006: pp. 96-97). In 1522, the Oromo started their liberation struggle to recover their lost homeland and liberate the conquered Oromo groups. According to Darrel Bates (1979: p. 7), "The [Oromo] ... had suffered in their time from both parties and were waiting in the wings for opportunities ... to recover lands that [were] taken from them." The wars between Christians and Muslims endangered the Oromo's survival as a people. With the renewal and reorganization of gadaa, the Oromo carried out butta wars every eight years, when power transferred from one gadaa grade to the next.

At the beginning of the sixteenth century, when they intensified their territorial recovery through the butta wars, many Oromo branches were under one gadaa government. The gadaa organization reconsolidated the Oromo people militarily and organizationally and enabled them to recover their lost territories and accommodate their increased population and stock (Legesse, 1973). The Oromo fought twelve butta wars between 1522 and 1618, recovering and reestablishing the Oromo country called Oromia today (Ta'a, 1986). According to The Oromos (1971: pp. 12-13), 'the sixteenth century's so-called 'Galla invasion'1 was neither an invasion nor a migration. It was rather a national movement of the Oromo people incited by the southern Oromo and supported by the northern Oromo then under the domination of the Abyssinians with the specific goal of liberating themselves and their territories from colonial domination." Between 1855 and 1868, under the leadership of Tewodros, the Amharas began major campaigns to either colonize and convert the Wallo and Yejju Oromo to Orthodox Christianity or expel or exterminate them (Crummey, 1971: pp. 107125). Before this period, the Wallo, Yejju, Azabo, and the Raya Oromo had accepted Islam "as a bulwark against being swamped by Abyssinian nationalism" (Trimingham, 1965: p. 109). The Ethiopian rulers had feared Islam and the Oromo since the sixteenth century, "and the thought of the two in combination has been their recurring nightmare" (Baxter, 1978: p. 285). Tewodros mobilized the Abyssinians against the Oromo by reintroducing this fear (Abir,

${ }^{1}$ Galla is a derogatory name given to the Oromo by their enemies; it connotes primitiveness or backwardness. 
1968). After he defeated the Yejju Oromo dynasty of Ras Ali II in 1853, he concentrated on the de-Oromoization of the Wallo region; his first campaign of terrorism, mutilation, and killing began in 1855 (Crummey, 1971). He also took extreme actions against the Tulama Oromo and eliminated the Oromo living between Dabra Berhan and Angolala (Crummey, 1971: p. 112). Despite his brutal campaigns and the attempt to deport the Wallo Oromo en masse to western Abyssinia, Tewodros failed to control them effectively Crummey, 1971: p. 118).

Surrounded in 1868 by the British expedition and near defeat, Tewodros released other prisoners and expressed his hatred for the Oromo by massacring some 1000 Oromo captives (Waldhaansso, 1979: pp. 19-20). He then committed suicide. Thus, he lost his life before unifying Abyssinia proper and colonizing the Oromo; the Wallo, Raya, Azabo, Yejju, and Tulama Oromo had successfully defended themselves. In the last decades of the nineteenth century, Yohannes IV and the Amhara king, Menelik II, allied with rival European powers to centralize their political power and expand their territories by participating in "the scramble for Africa." When the rivals-Britain, France, Russia, and Italy-sought alliances to obtain jumping-off places in the Horn so that they could create their spheres of influence in the region, Yohannes and Menelik, with the assistance of these imperialist powers, began to lay the foundations of the Ethiopian central state administration. However, the two rulers had earlier established a base for cooperation. Yohannes and Menelik started their alliance by helping the British to destroy their stronger rival, Tewodros. Tewodros of Amhara, who tried to centralize Ethiopia politically, was unsuccessful because of the lack of "both resources and experience needed to handle the European powers properly" (Venkataram, 1973: pp. 129-145). To assist the British in destroying his rival, Yohannes obtained rewards in military technology and army expertise. The elimination of Tewodros opened a new opportunity for Yohannes. Yohannes became the emperor of Ethiopia in 1872. He reigned as emperor until 1889 and came into conflict with the Mahdist state of Sudan and the Italians who had occupied the Red Sea basin.

Due to the geographic location of his political center, Yohannes was under severe external political pressure: The Italians were expanding their territory from the Red Sea coast to Tigray and allying and consolidating Menelik in Shawa; the Mahdists were penetrating through Gondar. There was a counterpart to the political space created for Yohannes by the British expedition that removed Tewodros from power-the Mahdists killed Yohannes in 1889. They developed an equal political opportunity for Menelik, who transferred the center of power from Tigray to Shawa (Caulk, 1971: pp. 23-42). There were two patterns of colonization: conquest and settlement. Menelik's first and foremost concern was to colonize the Oromo regions bordering on Manz (Shawa) (Gabre Selassie, 1975: p. 89). He occupied the Wallo Oromo kingdoms between 1868 and 1876. At roughly the same time, Menelik's army colonized the Liban Oromo. The Gulale, 
Yaha, Wachbacha, Bamici, and Mettaa Oromo came under Amhara control in 1978. Menelik occupied the eastern Oromo region in 1882. He organized expeditions "during times of famine when numerous refugees went along to settle in newly conquered lands with the soldiers who stayed behind to garrison the fortified villages (katamas)" (Marcus, 1975: pp. 64-65). Through his Amaharized Oromo general, Gobana Daci, Menelik made some Oromo leaders submit to Ethiopian rules, such as the Jimma and Wallaga kings.

Gobana, who once opposed Tewodros' anti-Oromo policy, welcomed Menelik and joined his court (Tafla, 1967: pp. 145-150). After Tewodros died in 1868, the Gobana-Menelik link developed into an alliance against Oromo leaders who opposed Menelik's political agenda. How did Gobana, who fought Tewodros and later killed some of Yohannes's soldiers that came to his area (Tafla, 1967: pp. 145-150), decide to collaborate with Menelik against his people? Sahile Selassie occupied Gobana's birthplace and imposed Orthodox Christianity on the Oromo who lived there. Mohammed Hassen (1981: p. 11) asserts that he "was born into a Christian Oromo family, where the policy of forced Amharization weighed heavily, permeating the whole atmosphere, affecting the family, their psychological attitudes and their whole manner of life.” Although Gobana was bilingual (Afaan Oromo and Amharic), he preferred to talk in Amharic (Hassen, 1981: p. 6). In addition to Amharization, Gobana had developed a strong interest in his military career in Menelik's army. As soon as Gobana began to provide his military service, Menelik appointed him as abagaz, chief palace guard (Hassen, 1981: p. 14); later, Menelik appointed him to the commander of the armed forces. The process of Amharization and political ambition turned Gobana against his people (Hassen, 1981: p. 15), and now any Oromo who has collaborated with the Ethiopians is called Gobana-traitor. Gobana later received the title of ras (head). Menelik made him a king of Kaffa, although Gobana was not appointed king of this region after assimilating into the Ethiopian Empire (Tafla, 1967: p. 148). Menelik was working on various levels in building his Empire. His alliance with European imperialism to obtain necessary items was fundamental. His attempt to create a collaborative class in the Oromo was secondary. Gobana helped Menelik in building the Ethiopian Empire and then lost his authority. To consolidate friendly relations with Gobana, he arranged a political marriage between his daughter and Gobana's son. Political marriage was an essential device in welding the interests of the families of regional rulers (Tafla, 1972: pp. 13-21).

There were Amharas who disliked Gobana's growing influence and power. By gradually removing Gobana and his supporters, Menelik appointed Amhara governors and prevented Gobana from establishing his political base among the Oromo. Menelik sent Gobana on further colonial expeditions in remote areas and assigned him to perform various military services until Gobana died in 1889 . Yates does not explain why Menelik gradually removed Oromo leaders like Gobana from the Ethiopian power structures by claiming that the northern Oromo 
and Menelik created the modern Ethiopian state. The Ethiopians conquered the Oromo, and they established garrison towns through which they channeled to Menelik's court products in the form of gold, grain, and honey (Triulzi, 1973: pp. 143-144). With the produce collected from Oromia, Menelik continuously purchased large quantities of weapons and military expertise from Europe (Hassen, 1981: p. 17). The Amhara colonial expansion resulted in mass killings, destruction, and appropriation of property, plundering, enslavement, and genocide (Marcus, 1975: p. 67). The massacre and enslavement of the Oromo continued through various colonial means (Danaldon, 1896: pp. 123127; Bulatovich, 2020; Melba, 1980). On October 13, 1892, the Menelik administration issued a proclamation to establish a10 percent tax (asrat) on agricultural produce to obtain provisions for its soldiers and ordered soldiers to leave houses in which they quartered (Rosenfeld, 1981: p. 157). Between 1896 and 1910, collecting revenue was gradually changed from the tribute system to taxation. With more state infrastructures, the government needed to obtain more money for its treasury through taxation. To pay for increased imports of firearms and luxury items, the Ethiopian ruling class aimed at increased produce extraction.

The state forced the rural population to produce for the state and its functionaries in addition to payments of tribute, tax, and fines. In Oromia and other colonized regions, the colonial state established the nafxanya-gabbar institution (semi-slavery) to coerce colonized farmers to provide food, other commodities, and labor and pay taxes to the settlers and the state. The Ethiopian farmers paid fixed taxes and special fees to their ruling class. The appropriation of produce from the farmers in the form of rent in kind, money rent, and labor rent existed simultaneously. The creation of the Ethiopian Empire through the penetration of imperialism did not introduce fundamental changes in the technology and organization of production except in productive relations, and then mainly in the colonized region. The state and its functionaries created numerous hudad (estate farms) all over the Empire, and the state coerced the farmers to work on them as part of their labor obligations (McCann, 1986: pp. 369-411). These estate farms produced all necessary products for consumption and market. Although there were such estate farms, the farmer household economy remained the basic unit of production. The state forced both the Ethiopian and the colonized farmers to engage in their household economies and make their payments in products and labor. However, the labor burden was more significant than that of the production.

\subsection{Habasha Settler Colonialism and Its Institutions}

Yates does not explain the political economy of Ethiopian settler colonialism and how the Habasha colonialists have oppressed, dehumanized, and exploited the Oromo and other colonized peoples. Habasha settler colonialism developed five forms of institutions in Oromia: the katamas (garrison cities), which were an 
integral component of a larger grid of towns, slavery, the balabat system, the nafxanya-gabbar system, and the colonial landholding system. The Habasha colonial settlers hierarchically organized the katamas in Oromia as their main geopolitical centers for practicing political domination through various control agencies, wealth and capital accumulation, and religious and cultural dissemination. The colonialists used the katamas as nerve centers of the colonial system for implementing colonial political, economic, and ideological programs; they were hierarchically organized as the principal, provincial, and subdistrict towns so that chains of command would flow from the center to the local level without any interruption. These garrison towns were established in strategically and politically secured places and became centers of regional rule and trade networks connecting various parts of Oromia to Ethiopia and Europe. They constituted nodal points of a more extensive countrywide network of towns that, woven, territorially organized the relational structure of Ethiopia's political economy, including the colonialist rule and the flow of products. The garrison cities were geopolitical headquarters. The colonialists dispatched soldiers to impose colonial rule through enslavement, subjugation, and appropriation of the primary means of production, such as cattle, land, and other valuables. Through these centers, expropriated goods flowed for local consumption and an international market.

Menelik established garrison towns in Oromia based on strategic and political considerations until he obtained massive firearms in the 1880s. Menelik and his rases built their garrison settlements (except Addis Ababa) on mountains and hills that they considered safe even after receiving these arms. Menelik consolidated his garrison town of Warra Illu in Wallo, northern Oromia, in 1870 and installed 40,000 soldiers there (Pankhurst, 1985: p. 226); in the same year, the Wallo Oromo attacked and destroyed it. After Yohannes imposed an overlordship on Menelik in 1878, the latter agreed at the Council of Borumeda in the same year to convert the Muslim Oromo coercively into Ethiopian Orthodox Christianity (Pankhurst, 1985: p. 227). Yohannes left the administration of the Wallo Oromo to his vassal, Menelik. There were several Europeans at the re-created Warra Illu garrison town in 1879. The Wallo Oromo set fire to this town again and destroyed it in the same year. The Wallo Oromo had played a significant role in weakening Habasha power since the sixteenth century by isolating the Amhara from the Tigray (Greenfield, 1965: p. 97): Northern Oromia, which was strategically and politically important, gradually fell into Ethiopian hands. After bringing this strategically and politically significant region under his control, Menelik turned his attention to the Tulama Oromo. With the further colonization of the Oromo, the building of more katamas became essential. Richard Pankhurst comments that "Political consideration... the desire to exercise

${ }^{2}$ This system had a historical root in Ethiopian landholding systems. Those medieval Habashas who occupied the land of the Agawu and other peoples were called Aqni Abbat (colonizing pioneers), and their descendants who nherited thatland were called balabats. Gradually, the balabat system was developed as the lower advantageous social position in the Ethiopian social structure. After Ethiopia colonized Oromia, the balabat system was modified and transplanted there toassist in developing the intermediate class from the colonized populations. 
more effective control over the Oromo and to escape further interference from Yohannes, led Menilek [sic] in the latter part of 1878 to move further to the mountain of Wacaca where he dug the foundations for a new town".

After strengthening his army and accumulating massive firearms, Menelik built Addis Ababa, known by the Oromo name, Shagar/Finfinne, between 1886 and 1887 without primary strategy consideration (Pankhurst, 1985: p. 187). In this way, Ethiopia established its principal economic and political headquarter in the heart of Oromia and gradually finalized its colonization through owning and controlling the primary means of production and compulsion. Founding Addis Ababa, the colonialists dispossessed Oromo lands and forced some Oromo to seek refuge in distant places in fear that they might revolt (Garretson, 1974: p. 104). The central portion of the Oromo land on which the colonialists established this capital city by dividing it among thirty-one Habasha officials (Pankhurst, 1985: p. 204). Some Europeans and others had obtained Oromo lands from Menelik before the commodification of Oromo land by giving him gifts (Garretson, 1974: p. 109); however, by the proclamation of October 27, 1907, Oromo land became a commodity to be sold and bought. This proclamation "gave Ethiopian and foreign [European and other] landlords a great deal more security of tenure" (Garretson, 1974: p. 116). The creation of Addis Ababa facilitated the immigration of skilled workers from many parts of the world to the newly emerging Empire. Some of these immigrants bought tracts of land and built their houses, shops, and offices. Despite numerous tragedies, the Oromo always lived in areas surrounding Addis Ababa and were continuously forced to supply their produce and labor freely or cheaply to this city (Garretson, 1974: p. 190). Oromo who resisted colonialism were massacred or fled or became slaves, servants to, or manual workers of the colonialists, but a few, who accepted Ethiopian dominance and converted to Christianity, were assimilated and incorporated into the Ethiopian colonial system.

The introduction of new technologies, the expansion of trade, the 1889-1892 famine and cholera epidemics in the Ethiopian Empire, and the need to feed the unproductive ruling class and the army all induced the Ethiopians to look to neighboring Oromo lands that were rich in economic and human resources (McCann, 1987; Garretson, 1974: pp. 330-331; Caulk, 1978: pp. 457-493). The Ethiopians raided the crops and the cattle of the Oromo and other peoples to feed the famine-stricken Habashas (Pankhurst, 1966: pp. 271-294). The Ethiopian ruling class transplanted their fellow Habashas to Oromia and forced the Oromo to work for them by colonizing Oromia. The Ethiopian "migrant soldier-peasant had formed the flesh and sinew of... armies of expansion in the south and west, but revenues from northern [Ethiopian] peasant farms never were a significant source of revenue for Ethiopia's growth into a modern state" (McCann, 1987: pp. 57-58). For instance, when the Mahdists killed Yohannes in 1889 , most of his 70,000 soldiers joined Menelik's force as soldiers of fortune to participate in his colonial expansion (Pankhurst, 1968: pp. 51-65). In 1896, Me- 
nelik and his rases had between 107,600 and 150,000 soldiers who primarily settled in Oromia (Pankhurst, 1968: p. 65). However, Garretson (1974: p. 217) estimated between 60,000 and 250,000 soldiers in Addis Ababa alone between 1886 and 1910. These soldiers and other famine-stricken Ethiopians continuously occupied the Oromo lands, devastated their properties and lives, looted their grain and cattle, and enslaved those whom they captured in the fighting. John McCann notes that "Addis Ababa, with all the characteristics of a bustling frontier town, had become the nexus for trade, administration, and political intrigue... the organization of commodity exports swiftly emerged as the economic form most influential in setting imperial policy" (McCann, 1987: p. 19). The colonialists created several permanent settlements on naturally fortified areas because of the seriousness of the Oromo resistance. Akalou Wolde Michael (1973: pp. 1-16) asserts that with Ethiopia's geographical expansion, "garrisons were set up all over newly acquired territories to hold down the conquered people. To maintain the army, part of the conquered land and, indeed, even the conquered people themselves [the state assigned] gabbars... to the soldiers." These garrisons gradually developed into towns where the colonialists used Oromo labor and economic resources to build regulatory and service institutions such as offices, prisons, churches, and schools.

While creating the strategically and commercially critical geopolitical centers in Oromia, the colonialists also intensified slavery and created the balabat and the nafxanya-gabbar systems. To provide his produce to the settlers, the colonizers forced the subjugated farmer to work for his colonial master, intermediaries, and the state for a certain number of days each week. During this period, the conquered or raided captives enslaved either served as domestic slaves or exported as commodities to Arabia, Sudan, Egypt, Turkey, Zanzibar, Persia, and India (Garretson, 1974: p. 224; Firewu, 1972: pp. 127-152). The Ethiopian ruling class continued to recruit slaves as its primary labor force through military campaigns. Ethiopian colonialism reduced some Oromos and others to slaves and semi-slaves. While male slaves worked as porters, servants, and farmworkers, female slaves performed household duties such as carrying firewood, fetching water, grinding grain, cooking, cleaning, baby-sitting, and bearing and giving birth to young slaves. Ethiopian colonialism intensified the process of using peoples as commodities either for domestic labor or export, although to what extent is unresolved. In 1964, Pankhurst estimated that slave traders exported some 2.5 million slaves from Ethiopia in the nineteenth century (Pankhurst, 1968: p. 84; 1964: p. 228). Menelik and his wife had 70,000 domestic slaves (Pankhurst, 1968: p. 75). Menelik, "Ethiopia's greatest slave entrepreneur," use Marcus's phrase, used other commodities as well as slaves in exchange for modern weapons and military expertise (Marcus, 1975: p. 73). The Ethiopian colonialists continued to depopulate Oromia through the slave trade until the 1930s. The Italians abolished slavery to recruit cheap labor for their agricultural plantations in the Horn of Africa. 
Whereas the Oromo intermediaries (balabats) were given one-fourth of the expropriated Oromo lands and received Ethiopian titles (such as balambaras and grazmach), the patriotic Oromo leaders who continued to resist were physically eliminated or forced to live in forests while they fought against Ethiopian colonialism. In Ethiopian history, Gobana Daci and his Oromo followers were considered heroes, but heroic Oromo leaders, such as Tufa Muna, Sheik Tola, Wacho Dabalo, Seera, were considered bandits. To better enforce Ethiopian colonial rule, the colonialists established a local Oromo intermediate class. Although the primary objective of the local balabat system was to ensure the maintenance and reproduction of the Ethiopian colonial system, the immediate purpose was to facilitate the continuous supply of grain, labor, and other necessary materials for the settlers. John Markakis (1974: p. 107) explains that the balabats "proved themselves indispensable as intermediaries between the northern governors [ $\mathrm{Ha}$ bashas] and the southern masses [mostly the Oromo]. In return, they were accorded status and privileges and gradually emerged as a distinct group associated with the northern ruling group and emulating its dominant characteristics." Because they were unfamiliar with the language and culture, the colonialists would have faced severe difficulty establishing their colonial rule in Oromia without this local intermediate class.

The Oromo collaborators became the instrument of the colonialists. They accepted this role because it provided economic and political advantages. Since the colonization of Oromia, the waves of collaboration and resistance have existed side by side. Scholars who reduce contradictions in the Ethiopian Empire only to class perspective fail to grasp how closely interlocked class and national contradictions. Those scholars who talk only from the standpoint of a class struggle confuse the place of the Oromo nation with that of the intermediate Oromo class that has been Ethiopianized. The Ethiopian colonial system has a place only for this class. Since this group functions within the Ethiopian interest and has acted against the Oromo, national and class contradictions are inseparable in the Oromo issue. Another institution that entitled the colonialists and their intermediaries to exact labor and agricultural products from the Oromo and others was the nafxanya-gabbar system. The Ethiopian settlers-soldiers, clergymen, and administrators (all known as nafxanyas)—exploited gabbars by forcing them to provide food, labor, tribute, and tax revenues in cash and in-kind (McClellan, 1978: p. 114). A ras or dajazmach might have received 1000 gabbars, a subgovernor 200 or 300, a fitawrari 300, a kangazmach 150, and ordinary soldiers, according to their rank, 20, 15 or 10. According to Michael Stahl (1974: p. 46), "The lords demanded from one-third to one-half of the harvest. In addition, they had to provide chicken, eggs, sheep, and beer for lords' banquets on important holidays."

The colonialists forced the farmers to work on estate farms and building roads and other construction projects. The control of gabbar labor and the expropriation of land were inseparable phenomena. Initially, land without delivery had lit- 
tle value, so the colonialists needed gabbars who would work for them. The state expropriated the best lands and appointed stewards (called misilenes) to manage hudads (estate farms) and gabbar labor. Local leaders facilitated the communication between the misilenes and the gabbars. In addition to paying tributes, taxes, and levies, the gabbars produced food and raised cattle, horses, and other animals for the emperor and his officials. The emperor and royal households owned extensive tracts of the best lands that supplied necessary provisions.

Local and regional state officials forced the gabbars to work on estate farms. These farms produced all the required products for consumption and market. Despite such farms and a few concession farms, the rural household economy remained the basic production unit. In Oromia, the primary sources of revenue gradually became gabbar labor and land for the colonial state and its officials. Initially, this colonial state financed itself by gains obtained from looting, the enslavement of the colonized peoples, and trade control. Gradually, however, gabbar labor and land became the primary sources of state revenue. "The system of land ownership was of crucial importance to the country's economic and social life," writes Pankhurst (1968: p. 135), "for besides determining questions of social class, it was the basis of administration, taxation, and military service." The state's governors, military commanders, soldiers, and settlers safeguarded Ethiopian control and product extraction. The Ethiopian colonialists settled fellow citizens in Oromia to perpetuate their dominance. Discussing this condition, John McCann (1986: p. 369) writes, “A key component of this process has been the movement of people out of... Abyssinia's empire into the south [mainly Oromia], first as soldiers/settlers and then as landlords, administrators, and political entrepreneurs."

The colonial state claimed absolute rights over three-fourths of the Oromo lands and provided portions for its officials instead of salary. The state rewarded the Ethiopian nobility and ecclesiastical, civil, and military officers with maderia and rist-gult ${ }^{3}$. The Ethiopian farmers and foreign mercenaries who participated in the colonization of Oromia as soldiers, settlers, messengers, priests, spies, and correctional officers were also granted land as a reward for their service. The amount of land (whether given temporarily or permanently) depended on rank or position. An ordinary soldier received from one to three gashas (a gasha is approximately forty hectares), a captain of fifty soldiers was granted up to five gashas, and a leader of three hundred soldiers received up to twenty gashas lands (Markakis, 1974: p. 113). The state also commodified and sold some lands to individuals. The state divided the remaining one-fourth of the colonized land among the Oromo collaborators. The state created or consolidated local landlords who were ready to serve between the Oromo and the colonialists. For instance, in the Arssi region, the state distributed about 96 percent of the land among the settlers and put the remainder under the control of the local intermediary group (Poluha,

${ }^{3}$ The land of the colonized Oromo that was given temporarily to the settlers in lieu of salary was called maderia. When the land was converted into the property of the holder and became salable and inheritable, it was called rist-gult. 
1974: p. 59). The Oromo farmers and pastoralists faced a similar fate everywhere. The state granted one-fourth of the land to the Oromo collaborators, and one person from each subgroup took charge of it. Such persons collected taxes and then paid them to the colonial settlers and the state. The colonialists separated the Oromo farmers from their primary means of production-cattle and land-to be enslaved and serve as gabbars to the colonial masters without payment. They received from their products only "that amount of food necessary for not dying of hunger" (Cited in McClellan, 1978: p. 124). Until tenancy emerged in the mid1930s, the nafxanyas used slave and gabbar labor for coffee and food production until Italian colonialism uprooted it in the mid-1930s.

\section{Discussion and Conclusion}

Being an African American, Yates should have been sensitive to the history and culture of the Oromo people who have been victimized, enslaved, and colonized like his people. Instead, he erases the identity of the Tulama and Wallo Oromo. He equates it with the essence of those collaborator individuals such as Gobana. These elites committed cultural suicide to take Habasha identity by promoting their interests at the cost of their people. Individuals and groups assimilated to the colonizing cultures in all colonized societies, but they have never represented their respective people. Writing this controversial book, when all colonized groups such as the Agao, Qimant, and the Oromo are engaging in national self-determination to overthrow Amhara colonial domination, and racism in the Amhara Regional state forces us to ask a serious question with the author? Is he an intellectual mercenary who promotes the interest of the Amhara colonial elite, or is he a naive scholar who has failed to understand the history and culture of the colonized, enslaved, and dehumanized people? Yates' intellectual effort to go beyond the current paradigms of Ethiopian and Oromo studies to explain the formation of the modern Ethiopian state is commendable. Unfortunately, the author does not critically analyze the contradictions involved in the cultural, political, and economic interactions of the Tulama and Wallo Oromo with various Habasha kingdoms.

He specifically focuses on and explains how members of the Tulama and Wallo Oromo elites joined the Amhara community by converting to Christianity, joining the military, speaking Amharic, marrying into Amhara families, and adopting Amhara cultural and political practices. Focusing on personal and family relationships between the dominant Amhara elite and the subordinate and collaborator Oromo elite does not explain how these relationships affected the farmers and pastoralists of the Tulama and Wallo Oromo. These relationships involved various forms of conflict, war, slavery, banditry, robbery, and expropriation of cattle and land. There is no question that the Oromo intermediaries became Habasha and incorporated into the highest Amhara power structures by demonstrating their loyalty to the leaders of the Amhara or Tigrayans. As Yates uses, the concept of the Habasha community is very abstract. He does not use critical 
historical and political economy analytic approaches to explain the political, economic, and cultural contradictions that existed in the Oromo communities of Tulama and Wallo and Amhara society to unpack what the Habasha community is.

These contradictions cannot be adequately explained and understood without addressing the processes of domination and subordination, culture, ethnicity, or ethnic-nation as analytical categories. Yates assumes that the Tulama and Wallo Oromo became Habasha and formed the modern Ethiopian state with the Amhara-Tigray elite by ignoring class and ethnonational contradictions. This assertion does not explain how Menelik colonized the Oromo people by using an Oromo collaborative class, which became the tool of oppression and exploitation in Oromo society. The Amhara state elite imposed two forms of oppression: class and ethnonational oppression in Oromo society and consolidated class oppression in Amhara-Tigray society. Consequently, the intellectual contribution of the book is minimal; it is biased against the Oromo people. Knowingly or unknowingly, Yates promotes the political and philosophical agenda of the Amhara elites, who are struggling to maintain their dominance in the Ethiopian Empire at the cost of the conquered, dominated, and exploited various population groups, particularly the Oromo. The Tulama and Wallo Oromo have rights like their Oromo brothers and sisters to maintain their Oromo culture and identity and achieve self-determination, social justice, and democracy without being forced to accept Habasha identity.

\section{Conflicts of Interest}

The author declares no conflicts of interest regarding the publication of this paper.

\section{References}

(1971, May). The Oromos: Voice against Tyranny (pp. 10-11). Reprinted in May 1980.

(1979, August). Waldhaansso: The Journal of the Union of Oromo Students in North America, 19-20.

Abir, M. (1968). Ethiopia: The Era of the Princes, the Challenge of Islam, and the Reunification of the Christian Empire, 1769-1855. Praeger Publishers.

Ayana, D. (2019). The Northern Zanj, Demadim, Yamyam, Yam/Yamjam, Habasha/Ahabish, Zanj-Ahabish, and Zanj ed-Damadam-The Horn of Africa between the Ninth and Fifteenth Centuries. History in Africa, 46, 57-104.

https://doi.org/10.1017/hia.2019.10

Bates, D. (1979). The Abyssinian Difficulty: The Emperor Theodrorus and the Maqdala Campain. Oxford University Press.

Baxter, P. T. W. (1978). Ethiopia's Unacknowledged Problem: The Oromo. African Affairs, 77, 283-296. https://doi.org/10.1093/oxfordjournals.afraf.a096985

Budge, E. A. W. (1932). The Queen of Sheba and Her only Son Menyelek I. Medici Society.

Bulatovich, A. (2000). Ethiopian through Russian Eyes: Country in Transition, 1896-1898 (Translated by Richard Seltzer). Red Sea Press. 
Bulcha, M. (2011). Contours of the Emergent \& Ancient Oromo Nation. Casas Book Series 84 .

Caulk, R. (1978). Armies as Predators: Soldiers and Peasants in Ethiopia C. 1850-1935. International Journal of African Historical Studies, 11, 457-493. https://doi.org/10.2307/217313

Caulk, R. A. (1971). Yohannes IV, the Mahdists, and the Colonial Partition of North-East Africa. Transafrican Journal of History, 1, 23-42.

Crummey, D. (1971). The Violence of Tewodros. The Journal of Ethiopian Studies, 9, 107-125.

Crummey, D. (1980). Abyssinian Feudalism. Past and Present, 89, 115-138. https://doi.org/10.1093/past/89.1.115

Donaldson, S. (1896). Expeditions through Somaliland to Lake Rudolf. Geographical Journal, 8, 120-137.

Faqih, A. (2003). Futuh Al-Habasa: The Conquest of Abyssinia, 16th Century, Translated by Paul Lester Stenhouse. Tsehai Publishers.

Firewu, S. M. (1972). Ye Bariya Sim Ba Amharawu Bahil. The Journal of Ethiopian Studies, 10, 127-152.

Gabre Selassie, Z. (1975). Yohannes IV of Ethiopia: A Political Biography. Clarendon Press.

Gamst, F. C. (1970). Peasantries and Elites without Urbanism: The Civilization of Ethiopia. Comparative Studies in Society and History, 12, 373-392. https://doi.org/10.1017/S001041750000596X

Garretson, P. P. (1974). A History of Addis Ababa from Its Foundation in 1886 to 1919. Ph.D. Dissertation, Univ. of London.

Greenfield, R. (1965). Ethiopia: A New Political History. Frederick A. Praeger, Inc. Publishers.

Hable Selassie, S. (1972). Ancient and Medieval Ethiopian History to 1270. United Printers.

Hassen, M. (1981). The Oromo Nation under Amhara Colonial Administration. School of Oriental and African Studies, June.

Hassen, M. (2015). The Oromo \& the Christian Kingdom of Ethiopia. James Currey. https://doi.org/10.1017/9781782045809

Hoben, A. (1970). Social Stratification in Traditional Amhara Society. In A. Tuden, \& L. Plotricov (Eds.), Social Stratification in Africa. The Free Press.

Jones, A. H. M., \& Monroe, E. (1961). A History of Ethiopia. Clarendon Press.

Legesse, A. (1973). Gadaa: Three Approaches to the Study of African Society. Free Press.

Marcus, H. G. (1975). The Life and Times of Menelik II, Ethiopia 1844-1913. Clarendon Press.

Markakis, J. (1974). Ethiopia: Anatomy of a Traditional Polity. Clarendon Press.

McCann, J. (1986). Household Economy, Demography, and the Push Factor in Northern Ethiopian History, 1916-35. Review, 9, 369-411.

McCann, J. (1987). From Poverty to Famine in Northeast Ethiopia: A Rural History 1900-1935. Univ. of Pennsylvania Press. https://doi.org/10.9783/9781512804409

McClellan, C. (1978). Reaction to Ethiopian Expansionism: The Case of Darasa, 1895-1935. Ph.D. Dissertation, Michigan State University.

Megalommatis, M. S. (2007). Meroitic/Oromo Ethiopian Continuity: Call for a Research 
Project. The Journal of Oromo Studies, 14, 7-33.

Melbaa, G. (1980). Oromia (Finfinne).

Michels, J. W. (1991). The Axumite Kingdom: A Settlement Archaeological Perspective. Henok: The Journal of Historical and Philosophical Thought, 2, 63-80.

Oromia Culture and Tourism Bureau OCTB (2006). History of the Oromo to the Sixteenth Century (2nd ed.). Berhanena Selam Printing Enterprise.

Pankhurst, R. (1961). An Introduction to the Economic History from Early Times to 1800. Lalibela House.

Pankhurst, R. (1964). The Ethiopian Slave Trade in the Nineteenth and Early Twentieth Centuries: A Statistical Inquiry. The Journal of Semitic Studies, 9, 1.

https://doi.org/10.1093/jss/9.1.220

Pankhurst, R. (1966). The Great Ethiopian Famine of 1888-1892: A New Assessment. Journal of the History of Medicine and Allied Science, 21, 271-294. https://doi.org/10.1093/jhmas/XXI.3.271

Pankhurst, R. (1967). Tribute, Taxation and Government Revenues in Nineteenth and Early Twentieth-Century Ethiopia (Part I). Journal of Ethiopian Studies, 5, 37-87.

Pankhurst, R. (1968). Economic History of Ethiopia 1800-1935.

Pankhurst, R. (1985). History of Ethiopian Towns from the Mid-Nineteenth Century to 1935. Franz Steiner Verlag Wiesbaden Gmbh.

Poluha, E. (1974). A Social Anthropological Study of 5 Peasant Families in Munessa Village. CADU Publication.

Rosenfeld, C. P. (1981). Historical Dictionary of Ethiopia. Scarecrow Press.

Stahl, M. (1974). Ethiopia: Political Contradictions in Agricultural Development. Publications of the Political Science Association in Uppsala, No. 67.

Stitz, V. (1970). The Amhara Resettlement of Northern Shoa during the 18th and 19th Centuries. Rural Africana, 11, 70-81.

Tafla, B. (1967). Ras Gobana Daci, Abba Tegu, 1821-1889. The Journal of Ethiopian Studies, 2, 145-150.

Tafla, B. (1972). Marriage as a Political Device: An Appraisal of a Socio-Political Aspect of the Menelik Period, 1889-1916. The Journal of Ethiopian Studies, 10, 13-21.

Tamrat, T. (1972). Church and State in Ethiopia. Clarendon Press.

Trimingham, J. S. (1965). Islam in Ethiopia. Barnes \& Noble, Inc.

Triulzi, A. (1973). The Background to Ras Gobana's Expeditions to Western Wallaga in 1886-1888: A Review of the Evidence. Proceedings of the First United States Conference on Ethiopian Studies, East Lansing, 2-5 May 1973, 143-144.

Venkataram, K. (1973). Foreign Policy of Theodore II of Ethiopia: An Interpretation. TransAfrican Journal of History, 3, 129-145.

Wolde Michael, A. (1973). Urban Development in Ethiopia (1889-1925) Early Phase. The Journal of Ethiopian Studies, 11, 1-16.

Yates, B. J. (2020). The Other Abyssinians: The Northern Oromo and the Creation of Modern Ethiopia, 1855-1913. University of Rochester Press, viii+236. 